УДК 657.471

\title{
ПЛАНУВАННЯ ІННОВАЦІЙНОї ДІЯЛЬНОСТІ НА ОСНОВІ ВИТРАТНОГО ПІДХОДУ
}

\section{PLANNING OF INNOVATIVE ACTIVITY BASED ON COST APPROACH}

\author{
Черешнюк Оксана Михайлівна \\ кандидат економічних наук, доцент, \\ Західноукраїнський національний університет \\ ORCID: https://orcid.org/0000-0001-5067-3463
}

\author{
Chereshnyuk Oksana \\ West Ukrainian National University
}

\begin{abstract}
Стаття присвячена актуальним питанням планування інноваційного проекту на основі системного підходу й ідентифрікації витрат за етапами його реалізації. У складі інноваційної діяльності як системи виокремлено такі елементи: аналіз зовнішнього середовища, аналіз внутрішнього середовища, інноваційний процес та лаг, інновація й сорормовано їх ієрархічність за етапами інноваційної діяльності, а саме дослідження, інвестування і впровадження та місцем виникнення витрат. 3 метою акумуляції інсрормації про процес реалізації інновацій сорормовано облікові джерела інформації. Синергетичний ефект від використання моделі полягає в ефективному виборі поведінки вищого рівня управління, враховуючи цінову кон'юнктуру, досягнення конкурентних переваг, мінімізацію впливу мінливості ринку і взаємного зростання інвестиційної довіри зацікавлених сторін до співробітництва.
\end{abstract}

Ключові слова: інновації, інноваційна діяльність, інноваційний проект, дослідження інновацій, впровадження інновацій, інвестування.

Статья посвящена актуальным вопросам планирования инновационного проекта на основе системного подхода и идентифрикации затрат по этапам его реализации. В составе инновационной деятельности как системы выделены следующие элементы: анализ внешней среды, анализ внутренней среды, инновационный процесс и лаг, инновация и сформирован их иерархичность по этапам инновационной деятельности, а именно исследования, инвестирование и внедрение и местом возникновения затрат. С целью аккумуляции информации о процессе реализации инноваций сформирован учетные источники информации. Синергетический эфффект от использования модели заключается в эффрективном выборе поведения высшего уровня управления, учитывая ценовую конъюнктуру, достижения конкурентных преимуществ, минимизации влияния изменчивости рынка и взаимного роста инвестиционной доверия заинтересованных сторон к сотрудничеству.

Ключевые слова: инновации, инновационная деятельность, инновационный проект, исследования инноваций, внедрения инноваций, инвестирования.

The article is devoted to topical issues of innovation project planning based on a systematic approach and cost identification by stages of its implementation. The following elements are singled out as part of innovation activity as a system: analysis of the external environment, analysis of the internal environment, innovation process and lag, innovation and their hierarchy by stages of innovation activity, namely research, investment and implementation and cost center. The analysis of the external environment involves the study of customers, investors, suppliers, the legal framework, financial institutions, energy resources. Analysis of the internal environment includes research on financing, production technology, corporate culture, staff qualifications, technical equipment, risk management, organizational structure. At the stage of the innovation process is the planning, organization, coordination, acquisition or creation of the project and control over these elements. The result of innovation is technological, technical, marketing or management innovation and the effect of its implementation. In order to accumulate information about the process of innovation implementation, accounting sources of information have been formed. As innovative activity at all stages assumes occurrence of expenses taking into account features of branch objects of the analysis which are reflected in the account are grouped. The result of innovative activities can be a change of position in the external environment, which leads to the enrichment of the enterprise. However, in the internal environment there is a dynamic of a number of elements, namely cost reduction, increase in profit, increase in productivity, formation of complex use of raw materials, conditionally waste-free production, increase in productivity, formation of a positive image of 
the enterprise. The synergistic effect of using the model is to effectively choose the behavior of senior management, taking into account the price situation, achieving competitive advantage, minimizing the impact of market volatility and mutual growth of investment confidence of stakeholders in cooperation.

Keywords: innovations, innovative activity, innovative project, research of innovations, introduction of innovations, investments.

Постановка проблеми. Розвиток сучасної економіки визначає значну роль інноваційної діяльності, як ефрективного методу збереження конкурентних позицій. Проте, управління інноваційною діяльністю потребує значного обсягу ресурсів, а саме інфрормаційних, матеріальних, трудових та інших. Передумовою вибору інноваційного проекту є дані про зовнішнє середовище прямої дії (постачальників, споживачів, конкурентів) та опосередкованої дії (економічні, політичні, правові, науково-технічні, демографрічні й соціальнокультурні фрактори), які акумулюються протягом дослідження. Інорормація про внутрішнє середовище охоплює інфрормацію прямої та опосередкованої дії, а саме про стратегію, політику та місію підприємства і специоріку інноваційного процесу (відстеження тенденцій розвитку й актуальності науково-технічного прогресу, технології, нових видів ресурсів, певного обсягу фрінансування, потреб ринку, можливості бізнесу та ін.). Водночас, специоріка інноваційного процесу характеризується галузевими особливостями, термінами виконання, залежністю від впливу сировинних ресурсів і наявного кваліфрікованого персоналу та ін. Таким чином реалізація інноваційного проекту характеризується виникненням витрат, які доцільно точно ідентифрікувати на основі облікової інорормації з метою акумуляції та оптимізації.

Аналіз останніх досліджень і публікацій. Дестабілізуючі фрактори розвитку світової економіки зумовлюють серед науковців та практиків пошуку ефективних способів вирішення кризових явищ та методів подолання наслідків пандемії, а також збереження або покращення конкурентного становища. Вагомий внесок у вивчення теорії та практики планування інноваційної діяльності здійснили В. М. Архіпова [9], О.В.Бєлякова [10], О.М.Головня [7], А. О. Князевич [3], Д. Ю. Крамськой [4], І. Я. Кулиняк [5], Л. А.Лисенко [6], В. В. Луцяк [7], О. М. Полінкевич [8], Н. Л. Сапельнікова [10], І. А. Сільченко [9], Д. В. Солоха [10], Ю. В. Ставська [7], І. А. Ріжко [5], П. С. Харів [11].

Виділення невирішених раніше частин загальної проблеми. Однак, незважаючи на наявність значної кількості наукових праць, слід зазначити про недостатнє висвітлення питань стосовно планування інноваційної діяльності на основі витратного підходу 3 можливістю коригування фрінансових ресурсів необхідних для реалізації проекту.

Формулювання цілей статті (постановка завдання). Основними завданнями дослідження $є$ проаналізувати теоретичні та практичні аспекти застосування витратного підходу для реалізації інновацій.

Виклад основного матеріалу дослідження. Євроінтеграційні процеси в Україні першочергово стосуватимуться адаптації вітчизняного законодавства до норм і вимог Європейського Союзу. Тому доцільно дослідити основні закони та принципи інноваційної діяльності в ЄС як передумову фрормування інтегрованого вітчизняного законодавства.

Організація економічного співробітництва і розвитку, яка об'єднує 37 провідні світові держави (країни Європейського Союзу, США, Австралія, Швейцарія, Норвегія, Південна Корея, Японія) та Європейська статистична організація у методологічному документі «нструкція Осло. Рекомендації про збір і аналіз даних про інновації» [2, с. 18] зазначили, що інноваційна діяльність підприємства - це наукова, технічна, організаційна, фрінансова та комерційна діяльність, яка приводить до впровадження інновацій або була задумана для їх впровадження. Водночас інноваціями на рівні підприємства $є$ нові або вдосконалені товари, виробничі процеси, методи маркетингу чи організаційні методи, які використовують уперше («нові для всього світу», «нові для ринку») або $є$ вдосконаленням наявних, а новими тільки для даного підприємства.

У теорії інновацій превалюють два основних підходи до розвитку моделей інноваційного процесу, а саме: один з них - технократичний, згідно з яким науково-технічний прогрес визначають у вигляді технологічних можливостей; показує траєкторію економічного розвитку і загострення конкуренції, що змушує підприємців шукати нові науково-технічні парадигми на ранніх етапах реалізації інноваційної діяльності. Цей підхід супроводжується зростанням капіталомісткості науки як окремої галузі, що виробляє знання й продукує нові можливості для бізнесу. Другим $\epsilon$ тиск попиту, згідно з яким процес нововведень 
залежить від попиту, котрий ініціює дисрузію продуктових і технологічних інновацій, приводить до реструктуризації бізнесу, розчищає ринок для нових підприємців. Запити ринку і дотичних організацій (екологічна служба, соціальні організації та ін.) фрормують окремі вимоги до роботи підприємства й цим окреслюють перспективи інноваційної діяльності.

За такого підходу до побудови моделі інноваційної діяльності сучасні науковці виокремлюють низку переваг, серед яких - швидше реагування на зміни у зовнішньому середовищі, оновлення бізнес-моделі для отримання конкурентних переваг, побудова інноваційного мислення та фрормування гнучкості інноваційних процесів. Синергетичним ефектом використання кругової моделі $€$ зменшення цінового тиску для підприємств з фріксованою ціною на продукцію; конкурентні переваги та збільшення ринкових позицій, мінімізація впливу мінливості ринку і зростання інвестиційної довіри зацікавлених сторін.

Інноваційна діяльність охоплює процес доведення сорормованої ідеї або технічного винаходу до стадії практичного використання, що створює дохід та відображається у блоці «Ефективність». Для вітчизняних підприємств інноваційна діяльність полягає у впровадженні технологічних, організаційних, споживчих, соціальних та екологічних інновацій, які сприятимуть збагаченню підприємства і фрормуванню конкурентної переваги. Запропонована модель представлена на рис. 1, особливістю якої $є$ орієнтованість інноваційної діяльності промислових підприємств на зовнішнє середовище, яке безпосередньо чи опосередковано впливає на роботу бізнесструктури.

Згідно із запропонованою моделлю інноваційна діяльність - це циклічний структурований процес, що дає змогу переміщатися між етапами з урахуванням особливостей кожного з них, що у кінцевому підсумку приводить до позитивних результатів. Науковці засвідчують, що циклічний підхід допомагає підприємствам у зовнішніх мінливих умовах перебудовувати та вдосконалювати інноваційний процес 3 метою отримання конкурентної переваги, виконувати за сприяння інновацій бізнес-завдання, які пов'язані з підвищенням якості продукції або продуктивності [1].

У блоці «Зовнішнє середовище» перелічено ключові ринкові та економічні фрактори, що впливають на діяльність підприємства. До них належать розвиток технологій, зміни в законодавстві, макроекономічні тенденції, екологічні проблеми, демографічні зміни та ін. Сукупність таких фракторів створює додаткові ризики не тільки для інноваційної, а й для основної діяльності підприємства. Зовнішнє середовище як основний споживач операційної діяльності підприємства фрормує переваги в ідеях інноваційної діяльності.

Блок «Внутрішнє середовище» відображає технічний, технологічний, трудовий та соціальні фрактори роботи підприємства як ключові напрями інноваційної діяльності.

Кругова модель із зовнішнього боку окреслена блоком «Аналіз зовнішнього середовища» який передбачає вивчення зовнішніх факторів, які впливають на роботу бізнесодиниці. Отже, зовнішні перспективи підприємства створюють підґрунтя для реалізації зовнішніх запитів, що є передумовою ефективніших та своєчасних інноваційних процесів. наступний елемент кругової моделі - «Аналіз внутрішнього середовища» передбачає дослідження всіх внутрішніх фракторів. Спроможність підприємств створювати і комерціалізувати нововведення залежить першочергово від їх сприятливості до інновацій.

Елемент моделі «Інноваційні процеси та лаг» $€$ основним етапом інноваційної діяльності. Інноваційний процес відображається як сукупність дій, пов'язаних з ініціюванням, розробленням та виготовленням продукції шляхом упровадження нової технології та обладнання, що нададуть нові покращені властивості продукції, яка своєю чергою есрективніше задовольнятиме наявні й перспективні потреби споживачів і формуватиме конкурентні переваги на ринку. Результативність упровадження інновацій залежить від багатьох чинників, основним з яких $€$ швидкість інновацій, котру можна характеризувати такою економічною категорією, як інноваційний лаг - термін від виникнення ідеї та до моменту її впровадження і отримання доходів [3, с. 27]. Інноваційний лаг - суттєва складова інноваційного процесу, яка перебуває в зоні малопродуктивних витрат часу, але від якої значною мірою залежать динаміка та швидкість його здійснення.

Результатом інноваційної діяльності може стати зміна позицій в зовнішньому середовищі, що приводить до збагачення підприємства. Проте у внутрішньому середовищі відбувається динаміка низки елементів, а саме зниження собівартості, збільшення прибутку, зростання продуктивності, фрормування комплексного використання сировини, умовно безвідходного виробництва, збільшення про- 


\begin{tabular}{|c|c|c|c|c|}
\hline \multicolumn{3}{|c|}{ Зовнішнє середовище } & \multicolumn{2}{|c|}{ Внутрішнє середовище } \\
\hline 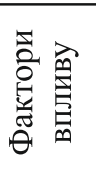 & $\begin{array}{l}\text { - економічні } \\
\text { - політико-інституційні } \\
\text { - науково-технічні } \\
\text { - екологічні }\end{array}$ & $\begin{array}{l}\text { - ресурсні } \\
\text { - демографічні } \\
\text { - соціально-культурні } \\
\text { - паливно-енергетичні }\end{array}$ & 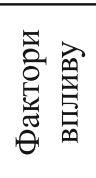 & $\begin{array}{l}\text { - технічні } \\
\text { - технологічні } \\
\text { - трудові } \\
\text { - соціальні }\end{array}$ \\
\hline
\end{tabular}

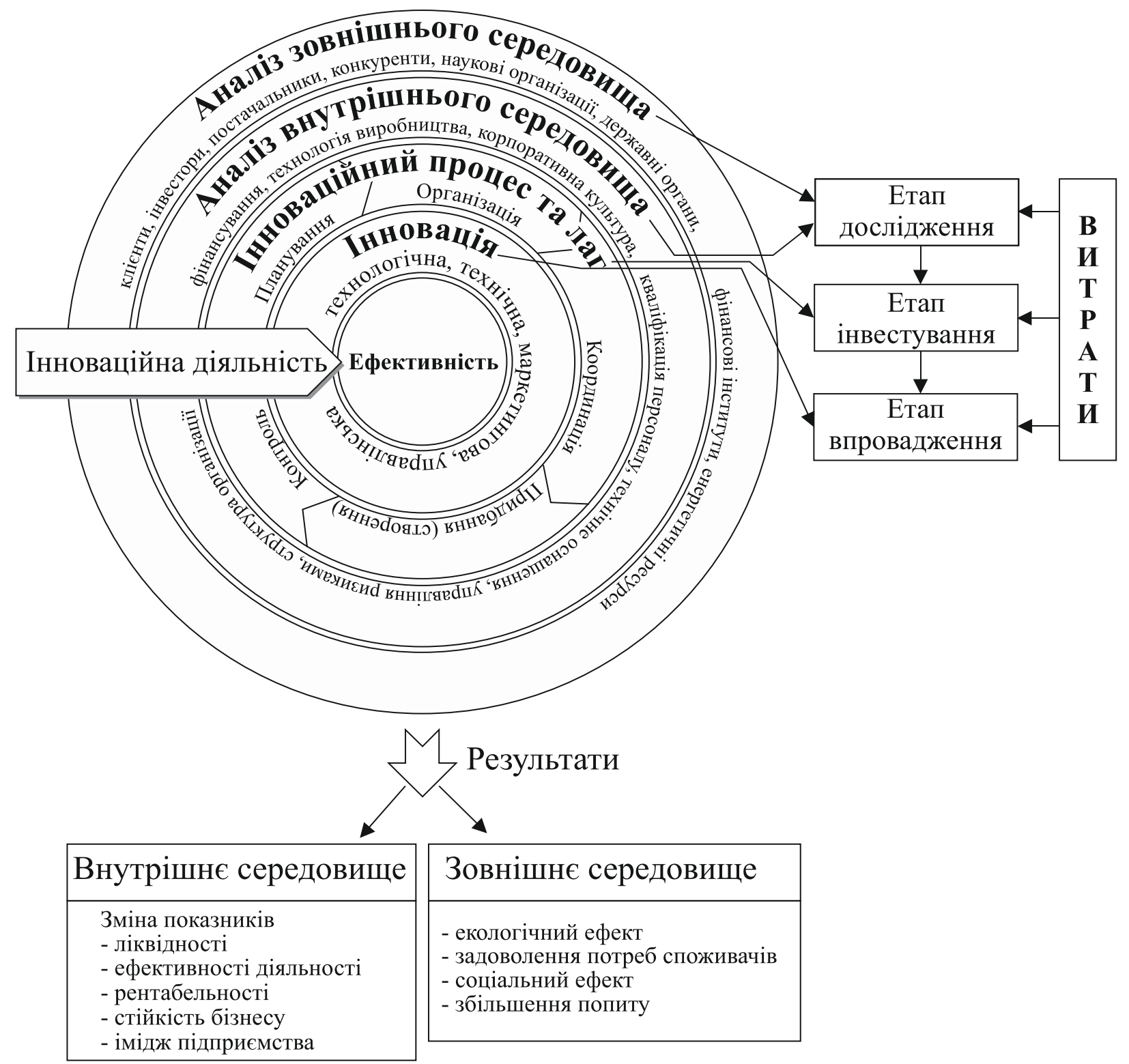

Рис. 1. Модель інноваційної діяльності на підприємствах побудована на основі ресурсного потенціалу підприємства

дуктивності, становлення позитивного іміджу підприємства. Важливим є досягнення синергетичного ефректу, а не концентрація уваги на поліпшенні окремих показників, що загрожує спроможності підприємства реагувати на зміни й ефективно реалізувати стратегію інноваційного розвитку. Дослідження окремого об'єкта і визначення його властивостей створює об'єктивну необхідність сорормувати мету й завдання інноваційної діяльності, яка полягає в наданні для власників, акціонерів, інвесторів, кредиторів, держави і контролюючих органів достовірної та обґрунтованої інфрормації про стан підприємства, а також проведення ана- 
лізу внутрішні й зовнішні фрактори впливу на срінансування проектів [11, с. 70].

Л. Лисенко зазначає, що для максимально всебічної й об'єктивної оцінки ефективності інноваційної діяльності доцільно виокремлювати найбільш вагомі її складові [6, с. 99]. Аналізувати інноваційну діяльність доцільно комплексно з урахуванням інших дотичних сорер впливу на означену роботу. А саме варто розглянути аналіз інноваційної діяльності як цілісну систему наукових знань, що обумовлено об'єктивним розвитком, диференціацією та інтеграцією економічної науки із запитами господарської практики [4, с. 253-255]. Зазначений підхід доповнюватиме структуру фрінансового аналізу низкою показників, що обґрунтують і структурують зміст окреслених даних.

Висновки. Вітчизняні промислові підприємства не мають чіткої політики розвитку, тому
3 метою вибору вектора інноваційної діяльності, формування інформації та її використання для управління запропоновано модель інноваційної діяльності на основі системного підходу й ідентифрікації витрат за етапами ії реалізації. У складі інноваційної діяльності як системи виокремлено такі елементи: аналіз зовнішнього середовища, аналіз внутрішнього середовища, інноваційний процес та лаг, інновація й сорормовано їх ієрархічність за етапами інноваційної діяльності (дослідження, інвестування і впровадження) та місцем виникнення витрат. Синергетичний ефрект від використання моделі полягає в ефективному виборі поведінки вищого рівня управління, враховуючи цінову кон'юнктуру, досягнення конкурентних переваг, мінімізацію впливу мінливості ринку і взаємного зростання інвестиційної довіри зацікавлених сторін до співробітництва.

\section{СПИСОК ВИКОРИСТАНИХ ДЖЕРЕЛ:}

1. A spiral approach to business model innovation. URL: http://www.ey.com/Publication/wwLUAssets/ Innovation/\$FILE/Innovation.pdf

2. Oslo Manual. Guidelines for collecting and interpreting innovation data (Third edition) 2005. URL: http://epp.eurostat.ec.europa.eu/cache/ITY_PUBLIC/OSLO/EN/OSLO-EN.PDF

3. Князевич А.О. Інноваційний лаг і його роль в інноваційному процесі. Актуальні проблеми економіки. 2010. № 6(108). С. 26-30.

4. Крамськой Д.Ю., Колотюк О.І. Аналіз інструментарію дослідження інноваційного розвитку підприємства. Бізнес Інфрорм. 2013. № 5. С. 253-258.

5. Кулиняк І.Я., Ріжко І.А. Аналіз інноваційної діяльності підприємств західного регіону України. Вісник Національного університету «Львівська політехніка». Проблеми економіки та управління. 2013. № 754. С. $26-33$.

6. Лисенко Л.А. Підхід до оцінки ефективності інноваційної діяльності підприємства. Комунальне господарство міст. Сер. : Економічні науки : зб. наук. пр. Харк. нац. акад. міськ. госп-ва. Харків, 2007. № 78. С. 94-100.

7. Луцяк В.В., Ставська Ю.В., Головня О.М. Стратегічне планування і тактика інноваційної діяльності у ресторанних підприємствах: розроблення функціональних харчових продуктів. Вісник Східноєвропейського університету економіки і менеджменту. Серія : Економіка і менеджмент. 2018. № 1. С. 103-113.

8. Полінкевич О.М. Принципи адаптивного планування інноваційної діяльності підприємств. Економічні науки. Серія : Економіка та менеджмент. 2018. Вип. 15. С. 205-211.

9. Сільченко І.А., Архіпова В.М. Планування як визначна необхідність розвитку інноваційної діяльності підприємств. Вісник Бердянського університету менеджменту і бізнесу. 2017. № 4. С. 63-67.

10. Солоха Д.В., Сапельнікова Н.Л., Бєлякова О.В. Управління інвестиційно-інноваційною діяльністю в системі бізнес-планування підприємств України. Менеджер. 2020. № 2. С. 127-139.

11.Харів П.С. Інноваційна діяльність підприємства та економічна оцінка інноваційних процесів. Тернопіль : Економічна думка, 2003. 326 с.

\section{REFERENCES:}

1. A spiral approach to business model innovation. Available at: http://www.ey.com/Publication/vwLUAssets/ Innovation/\$FILE/Innovation.pdf

2. Oslo Manual. Guidelines for collecting and interpreting innovation data (Third edition) 2005. Available at: http://epp.eurostat.ec.europa.eu/cache/ITY_PUBLIC/OSLO/EN/OSLO-EN.PDF

3. Knyazevich A.O. (2010) Innovacijnij lag i jogo rol v innovacijnomu procesi [Innovation lag and its role in the innovation process]. Aktual'ni problemi ekonomiki, 6(108), 26-30.

4. Kramskoj D.Yu., Kolotyuk O.I. (2013) Analiz instrumentariyu doslidzhennya innovacijnogo rozvytku pidpryyemstva [Analysis of research tools for innovative development of the enterprise]. Biznes Inform, 5, 253-258. 
5. Kulynyak I.Ya., Rizhko I.A. (2013) Analiz innovacijnoyi diyalnosti pidpryyemstv zaxidnogo regionu Ukrayiny [Analysis of innovative activity of enterprises in the western region of Ukraine]. Visnyk Nacionalnogo universytetu "Lvivska politexnika". Problemy ekonomiky ta upravlinnya, 754, 26-33.

6. Lysenko L.A. (2007) Pidxid do ocinky efektyvnosti innovacijnoyi diyalnosti pidpryyemstva [Approach to assessing the effectiveness of innovative activities of the enterprise]. Komunalne gospodarstvo mist. Ser.: Ekonomichni nauky: zb. nauk. pr. Khark. nacz. akad. misk. gosp-va. Kharkiv, 78, 94-100.

7. Lucyak V.V., Stavska Yu.V., Golovnya O.M. (2018) Strategichne planuvannya i taktyka innovacijnoyi diyalnosti u restorannyx pidpryyemstvax: rozroblennya funkcionalnyx xarchovyx produktiv [Strategic planning and tactics of innovative activity in restaurant enterprises: development of functional food products]. Visnyk Sxidnoyevropejskogo universytetu ekonomiky i menedzhmentu. Seriya: Ekonomika i menedzhment, 1, 103-113.

8. Polinkevych O.M. (2018) Pryncypy adaptyvnogo planuvannya innovacijnoyi diyalnosti pidpryyemstv [Principles of adaptive planning of innovative activity of enterprises]. Ekonomichni nauky. Seriya: Ekonomika ta menedzhment, 15, 205-211.

9. Silchenko I.A., Arxipova V.M. (2017) Planuvannya yak vyznachna neobxidnist rozvytku innovacijnoyi diyalnosti pidpryyemstv [Planning as a significant need for the development of innovative activities of enterprises]. Visnyk Berdyanskogo universytetu menedzhmentu i biznesu, 4, 63-67.

10. Soloxa D.V., Sapelnikova N.L., Byelyakova O.V. (2020) Upravlinnya investycijno-innovacijnoyu diyalnistyu $v$ systemi biznes-planuvannya pidpryyemstv Ukrayiny [Management of investment and innovation activities in the business planning system of Ukrainian enterprises]. Menedzher, 2, 127-139.

11.Xariv P.S. (2003) Innovacijna diyalnist pidpryyemstva ta ekonomichna ocinka innovacijnyx procesiv [Innovative activity of the enterprise and economic estimation of innovative processes]. Ternopil: Ekonomichna dumka, 326 p. (in Ukrainian) 